\title{
PENYARINGAN AIR KERUH MENGGUNAKAN SENSOR LDR DAN BLUETOOTH HC-05 SEBAGAI MEDIA PENGONTROLAN GUNA MENINGKATKAN MUTU KEBERSIHAN AIR DI SEKOLAH
}

\author{
Deny Nusyirwan $^{1^{*}}$, Michael Dudikof Aritonang ${ }^{2}$, Prasetya Perwira Putra Perdana ${ }^{3}$ \\ ${ }^{1,2,3}$ Fakultas Teknik, Program Studi Teknik Elektro, Universitas Maritim Raja Ali Haji \\ (UMRAH) Jl. Politeknik Senggarang, Tanjungpinang, Kepulaua Riau 29100 \\ Corresponding Author Email: denynusyirwan@umrah.ac.id
}

\begin{abstract}
ABSTRAK
Kesehatan merupakan kondisi fisik seseorang berjalan dengan baik dan normal.kesehatan dapat diperngaruhi oleh faktor internal dan eksternal,air merupakan salah satu dari faktor eksternal yang dapat mempengaruhi kesehatan,oleh karena itu sumber air untuk kebutuhan manusia haruslah bersih dan jernih serta bebas dari bahaya bakteri, mikroorganisme, logam berat , tingkat keasamaan, dan juga ph yang standard.. Oleh karena itu perancangan penyaring air keruh menggunakan module HC-05 sebagai media pengontrol alat guna meningkatkan mutu air di lingkungan sekolah yaitu SDN 011 TANJUNGPINANG TIMUR, inovasi ini berguna untuk mencegah pengguna air terjangkit oleh berbagai macam penyakit. Proses filtrasi air mempunyai beberapa tahapan yaitu module HC-05 akan menerima data dari android untuk menghidupkan pompa air, kemudian pompa air akan mentrasfer air ke filter guna menyaring kotoran,hasil penyaringan akan dialiri ke sumber air itu juga, lampu LED berwarna hijau sebagai indikator proses filterasi sedang berjalan,dan menggunakan lampu LED merah sebagai indikator alat sedang tidak beroperasi.Selain sederhana inovasi ini juga hamat daya karna menggunakan energi listrik yang sangat rendah sehingga lebih hemat energi,selain itu juga inovasi ini sangat berguna untuk menjernihkan air sehingga pengguna air di lingkungan sekitar tidak ragu dalam menggunakan air.
\end{abstract}

Kata Kunci: Kesehatan, Kejernihan, Air, Filterasi, Lingkungan Sekolah

\begin{abstract}
Health is a physical condition of a person running well and normally. Health can be influenced by internal and external factors. Water is an external factor that can affect health, therefore water sources for human must be clean from the dangers of bacteria, microorganisms, heavy metals, the level of acidity, and also the standard ph. Therefore the design of turbid water filters uses the HC-05 module as a tool to control the prototype to improve water quality in the school, namely SDN 011 TANJUNGPINANG TIMUR. This innovation is useful to prevent water users from being infected by various diseases. The water filtration process has several stages, $\mathrm{HC}-05$ module will receive data from android to turn on the water pump, then the water pump will transfer water to filter to filter impurities, the filtering results will be fed to the water source too, green LED lights as an indicator of the filtration process is running, and uses a red LED light as a tool indicator is not operating. In addition to this simple innovation also has power because it uses very low electrical energy so it is more energy efficient, besides that this innovation is very useful to purify water so that users of water in the surrounding environment no doubt in using water.
\end{abstract}

Keywords: Health, Clarity, Water, Filtration, School Enviroment 


\section{PENDAHULUAN}

Kesehatan merupakan kondisi yang dimana semua sistem metabolisme berjalan dengan sebagaimana mestinya,oleh karena itu kondisi fisik yang sehat merupakan dambaan bagi semua orang.jika kondisi fisik sehat maka banyak hal yang bisa dilakukan,seperti contohnya di sekolah mulai dari aktivitas belajar, bermain, berolahraga, serta banyak kegiatan lainnya, oleh karena itu, kondisi lingkungan disekitar siswa harus bersih dan higienis Untuk menjaga agar badan siswa sehat, selain itu kita harus memperhatikan kondisi air dalam lingkungann sekolah,khususnya air pada wc siswa-siswi.

Air yang terdapat di WC sekolah bersih dan jernih,terkadang masih ada air yang keruh dan berbau, sehingga air tidak layak digunakan untuk mencuci tangan, menyiram bunga,buang air,karena dapat menimbulkan berbagai macam penyakit.Terkadang siswa harus menggunakan air keruh yang berada di WC tersebut,karena tidak ada sumber air lagi untuk beberapa aktivitas ataupun keperluannya,padahal air tersebut sangatlah tidak layak,karena dapat menimbulkan berbagai macam penyakit. Beberapa diantaranya yaitu siswa terkadang mengeluh karena kondisi air keruh, siswa susah menggunakan air untuk buang air,karena terdapat bakteri ataupun parasite didalam air yang dapat menimbulkan berbagai macam penyakit.

\section{KAJIAN PUSTAKA}

Didalam penelitian ini, telah di lakukan kajian terhadap penelitian terdahulu yang akan di pergunakan sebagai batasan terhadap penelitian yang akan di lakukan, selain itu kajian pustaka juga akan menjelaskan mengenai purwarupa yang akan dirancang.

\section{Penelitian terdahulu}

Pada penelitian yang berjudul Rancang Bangun Filter Air Berbasis Arduino Pada Penampungan Air Menggunakan Metode Fuzzy adalah penelitian untuk menjaga air tetap pada tingkat kejernihan yang ditentukan sehingga layak untuk dikonsumsi dan dipergunakan untuk sanitasi. Sistem yang dirancang mempergunakan sensor kekeruhan yang akan mendetaksi tingkat kejernihan air, Sensor akan mengirimkan informasi kepada Arduino., apabila level kekeruhan berada pada batas yang ditentukan, maka arduino akan menggerakkan aktuator yang terintegrasi dengan pompa air sehingga proses penyaringan dimulai (Wiguna $\mathrm{dkk}, 2018$ ).

Sedangkan pada penelitian dengan judul alat penyaring air kotor menjadi air bersih menggunakan mikrokontroller atmega 32 menjelaskan sebuah sistem penyaringan air bersih menggunakan mikrokontroller ATMega32 sebagai pengatur kerja pompa berdasarkan s tingkat kejernihan air. Sistem operasi yang dipergunakan adalah Windows 7 dengan bahasa pemograman Basic - Bascom AVR dan Visual Basic 6.0. Hasil dari proses penyaringan akan ditampilkan di aplikasi pemograman dan juga pada LCD (Susanto dkk, 2014).

Penelitian dengan judul Alat Penyaringan Air Sederhana Dengan Metode Fisika menjelaskan mengenai pembuatan alat penyaringan air sederhana dengan menggunakan kerikil, ijuk dan arang sekam. Dari hasil uji coba didapatkan bahwa arang sekam sangat berperan didalam menjernihkan air, dimana semakin tebal makan air akan semakin jernih (Gusdi dkk, 2017).

Pada penelitian yang berjudul Sistem Kontrol Tingkat Kekeruhan Pada Aquarium Menggunakan Arduino Uno adalah sebuah penelitian untuk menjaga air tetap pada tingkat kejernihan yang dibutuhkan sehingga dapat meningkatkan harapan hidup embrio ikan. Sistem ini menggunakan arduino yang di integrasikan dengan sensor kekeruhan (turbidity sensor), apabila tingkat kekeruhan sudah berada pada batas yang ditentukan maka pompa air akan berfungsi, selanjutnya akan terjadi sirkulasi air melalui alat penyaring yang sudah disediakan sehingga air yang kembali akan memiliki tingkat kekeruhan yang lebih rendah (Ramadhan dkk, 2017).

\section{Landasan Teori}

Cara kerja dari purwarupa dimulai dengan sensor cahaya LDR yang tidak mendapatkan cahaya, selanjutnya mikrokontroller Arduino akan memberikan output ke buzzer untuk berbunyi dan LED merah untuk menyala, hal ini merupakan indicator bahwa air sedang keruh dan jangan dipergunakan. Selanjutnya pengguna dapat menjalankan pompa air untuk memulai proses filtrasi atau proses penjernihan air dengan menggunakan aplikasi Bluetooth yang terdapat 
di pada Android. setelah buzzer berhenti berbunyi dan LED merah berubah menjadi hijau menandakan air sudah jernih dan dapat dipergunakan yang terdapat pada Gambar 1.

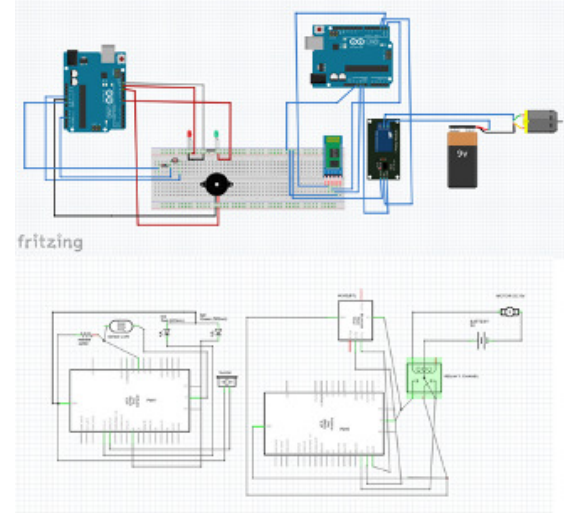

Gambar 1. Rangkaian elektronika sistem penyaringan air keruh menggunakan Sensor LDR dan Bluetooth

\section{Komponen purwarupa}

Adapun komponen yang diperlukan untuk pembuatan purwarupa dengan estimasi harga yang terdapat pada pada Tabel 1.

Tabel 1. Estimasi anggaran (Fabric Technology Surabaya/ Bukalapak, diakses 28 Mei 2019)

\begin{tabular}{|c|l|c|c|}
\hline No. & NAMA KOMPONEN & JUMLAH (Pcs) & HARGA (Rp) \\
\hline 1 & ARDUINO UNO & 2 & 88500 \\
\hline 2 & SENSOR LDR & 1 & 2500 \\
\hline 3 & MODUL HC-05 & 1 & 59500 \\
\hline 4 & LED & 2 & 1000 \\
\hline 5 & RESISTOR 220 ohm & 2 & 1000 \\
\hline 6 & BUZZER 5v & 1 & 3000 \\
\hline 7 & KABEL JUMPER MALE-MALE & 1 & 12500 \\
\hline 8 & KABEL JUMPER MALE-FEMALE & 1 & 12500 \\
\hline 9 & POMPA AIR MINI 6V & 1 & 29500 \\
\hline 10 & BATERAI 3,7V & 2 & 20000 \\
\hline 11 & PROJECT BOARD & 1 & 24500 \\
\hline & TOTAL & & 254500 \\
\hline
\end{tabular}

\section{Arduino UNO R3}

Arduino Uno R3 adalah merupakan sebuah mikrokontroller, dimana mikrokontroler tersebut akan memproses input yang diberikan melalui bahasa pemograman open source sehingga akan menghasilkan output. Cukup hubungkan Arduino dengan kabel USB ke PC atau Mac/Linux anda, jalankan software Arduino sudah bisa untuk memprogram chip ATmega328 yang terdapat pada Gambar 2.

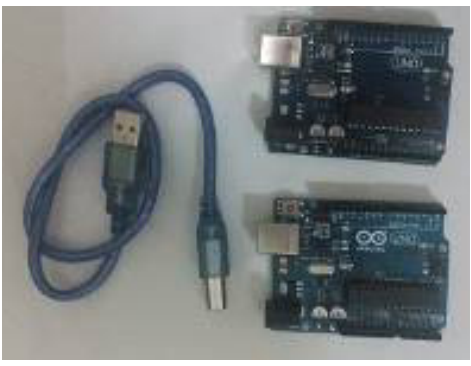

Gambar 2. Arduino Uno

\section{Breadboard}

Breadboard adalah dasar konstruksi sebuah sirkuit elektronik dan merupakan purwarupa dari suatu rangkaian elektronik. Breadboard banyak digunakan untuk merangkai komponen, karena dengan menggunakan breadboard, pembuatan purwarupa tidak memerlukan proses menyolder (langsung tancap ). Karena sifatnya yang solderless alias tidak memerlukan solder sehingga dapat digunakan kembali dan dengan demikian sangat cocok digunakan pada tahapan proses pembuatan purwarupa serta membantu dalam berkreasi dalam desain sirkuit elektronika yang terdapat pada Gambar 3.

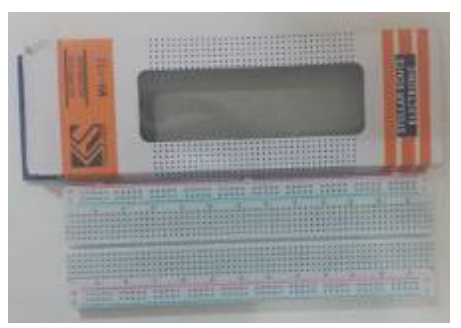

Gambar 3. Bread Board

\section{Kabel jumper}

Kabel jumper adalah kabel yang di pergunakan untuk menghubungkan satu komponen dengan komponen lain ataupun menghubungkan jalur rangkaian yang terputus pada breadboard yang terdapat pada Gambar 4.

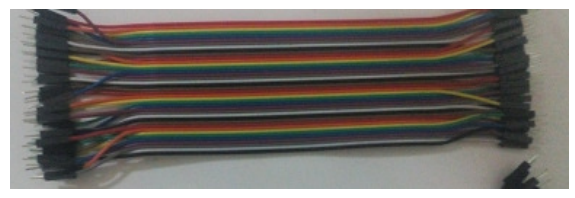

Gambar 4. Kabel Jumper

\section{Bluetooth}

Bluetooth adalah sebuah alat yang dipergunakan untuk menghubungkan sebuah perangkat dengan perangkat lainnya tanpa kabel yang terdapat pada Gambar 5.

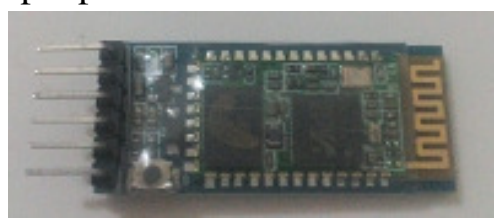

Gambar 5. Blueetooth

\section{Buzzer}

Buzzer adalah sebuah komponen yang akan menghasilkan suara melalui perubahan 
getaran listrik menjadi suara yang terdapat pada Gambar 6.

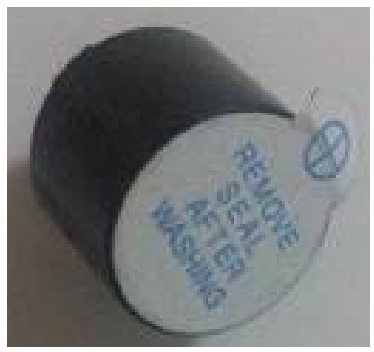

Gambar 6. Buzzer

\section{Resistor}

Resistor adalah komponen Elektronika Pasif yang memiliki nilai resistansi atau hambatan tertentu yang berfungsi untuk membatasi dan mengatur arus listrik dalam suatu rangkaian Elektronika. ungsi-fungsi Resistor di dalam rangkaian elektronika memiliki fungsi pembatas dan pengatur arus listrik, serta pembagi dan penurun tegangan listrik yang terdapat pada Gambar 7 .

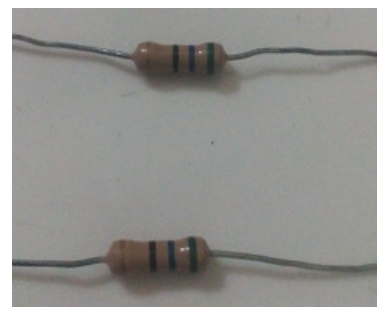

Gambar 7. Resistor

\section{Light Emitting Diode (LED)}

LED adalah sebuah komponen elektronika yang akan menampilkan cahaya apabila diberikan tegangan. Adapun bentuk LED mirip dengan sebuah bohlam (bola lampu) yang kecil dan dapat dipasangkan dengan mudah ke dalam berbagai perangkat elektronika. Berbeda dengan Lampu Pijar, LED tidak memerlukan pembakaran filamen sehingga tidak menimbulkan panas dalam menghasilkan cahaya. Oleh karena itu, LED dengan bentuk yang kecil telah banyak dipergunakan sebagai lampu penerang untuk mengganti lampu tabung, lihat Gambar 8.

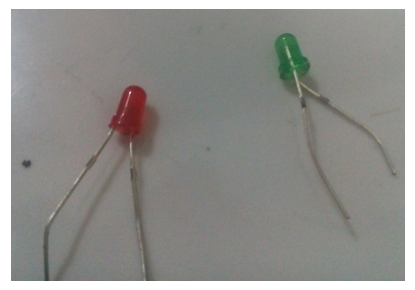

Gambar 8 . LED

\section{Pompa Air Mini}

Penggunaan pompa air mini berfungsi sebagai alat tranfer air dari sumber ke filter. Keunggulan dalam penggunaan pompa air mini yaitu minimalis atau praktis, mengugunakan tegangan rendah yaitu 5-6V sehingga lebih hemat dalam penggunaan energi yang terdapat pada Gambar 9.

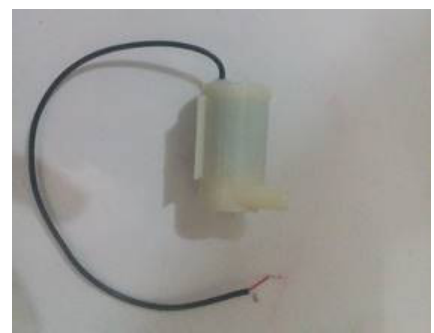

Gambar 9. Pompa air mini

\section{Sensor Cahaya LDR (Light Depenedent Resistor)}

Sensor LDR adalah jenis resistor yang perubahan resistansi nya tergantung dari besar kecilnya cahaya yang diterima.

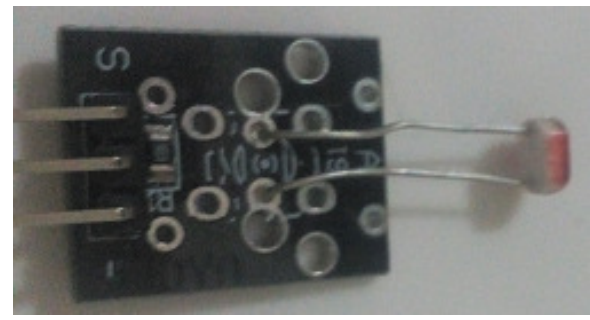

Gambar 10 .Sensor Cahaya LDR

\section{Baterai}

Baterai adalah sebuah alat penyimpan energy, yang merubah energi kimia menjadi energi listrik untuk dipergunakan oleh perangkat elektronik yang terdapat pada Gambar 11.

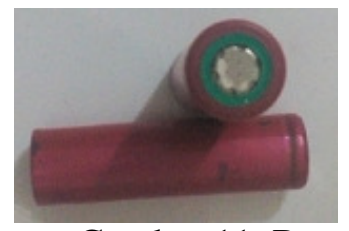

Gambar 11. Baterai

\section{METODE}

Peranan penting bagi ilmuwan pada abad ke-21 adalah berperan serta dalam mendidik masyarakat tentang metode dan hasil proses ilmiah (Kastner dkk, 2017), oleh sebab itu diperlukan proses desain rekayasa untuk mampu 
menghasilkan inovasi berbasiskan teknologi yang semakin berkembang dan memiliki fungsi yang tepat dan mudah untuk digunakan. Jika di masa lalu desainer dievaluasi hanya berdasarkan pada keterampilan teknis mereka, di masa depan akan lebih banyak lagi kebutuhan untuk desainer yang bersedia bekerja dengan pendekatan yang lebih sistemik dan strategis dalam skala yang lebih besar (Irbīte dkk, 2016). Proses Desain Rekayasa adalah merupakan sebuah proses didalam mendesain dengan berpusat kepada pengguna. dimulai dengan etnografi hingga menghasilkan sebuah purwarupa yang merupakan sebuah konsep solusi yang sesuai dengan kebutuhan di masyarakat.

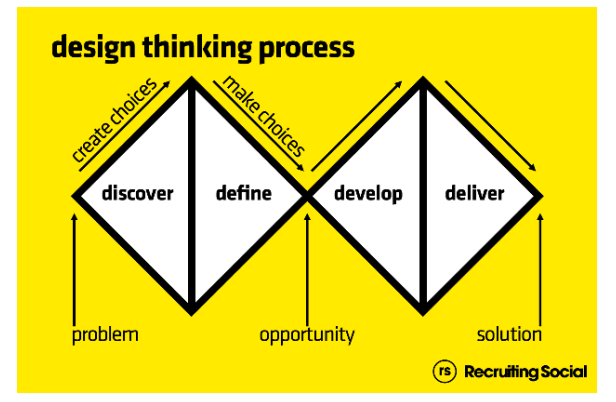

Gambar 11. Tahapan pada Proses Desain Rekayasa (https://id.pinterest.com)

Proses ini memiliki 4 tahapan, pada tahapan awal dimulai dengan observasi secara luas di masyarakat untuk mendapatkan permasalahanpermasalahan, tahapan kedua adalah proses pengerucutan dengan melakukan pemilihan permasalahan utama, tahapan ketiga adalah mengembangkan ide-ide sebagai solusi terhadap permasalahan utama dan tahapan terahir adalah menetukan solusi utama untuk dapat dilanjutkan ke tahapan pembuatan purwarupa dan pengujian terhadap pengguna, sila lihat Gambar 11 . Dalam tahapan pengujian terhadap pengguna akan terdapat proses iterasi untuk mendapatkan masukan untuk perbaikan inovasi nantinya.

Desain dan pemasaran adalah dua bagian penting dalam proses penelitian untuk melakukan pengembangan produk dan menghasilkan inovasi berbasis teknologi. Kedua bidang tersebut dapat saling melengkapi namun memiliki fokus yang berbeda. Peneliti untuk bidang desain sangat ingin tahu apa yang benarbenar dibutuhkan oleh calon pengguna dan bagaimana sebenarnya pengguna akan menggunakan produk yang sedang dipersiapkan. Sedangkan untuk peneliti di bidang pemasaran ingin tahu apa yang akan dibeli pengguna, termasuk mempelajari bagaimana pengguna membuat keputusan pembelian. Oleh sebab itu, dengan tujuan yang berbeda ini akan mengarahkan kedua kelompok tersebut untuk mengembangkan metode penyelidikan yang berbeda pula. Desainer cenderung menggunakan metode observasi kualitatif yang dengannya mereka dapat mempelajari orang secara mendalam, memahami bagaimana mereka melakukan kegiatan mereka dan faktor lingkungan yang ikut berperan. Metode ini sangat memakan waktu, sehingga didalam penelitian ini hanya memeriksa sejumlah kecil orang.. Adapun metode observasi yang dipergunakan adalah metode observasi peneliti sebagai peserta (observer as participant), yaitu kelompok yang sedang diteliti mengetahui tentang keberadaan peneliti, namun peneliti tidak ikut serta melakukan kegiatan dan aktifitas didalam kelompok yang sedang diteliti. Lokasi penelitian dilakukan di SDN011 Tanjung pinang timur, Kepulauan Riau, lihat Gambar 12.

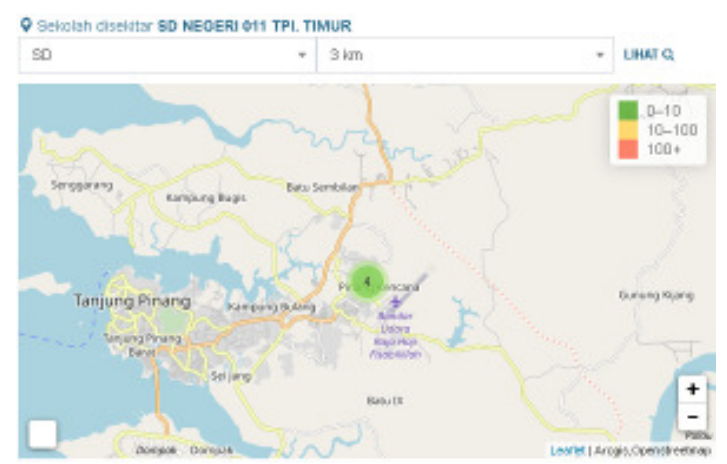

Gambar 12. Lokasi SDN 011 Tanjung pinang timur

Langkah awal dari Proses Desain Rekayasa, yang merupakan aktivitas pegamatan atau observasi secara langsung ke masyarakat di suatu daerah untuk mendapatkan data yang akurat sehingga mampu menghasilkan sebuah solusi yang tepat. Pada Gambar 13 menampilkan keadaaan di SDN 011 Tanjung pinang timur untuk mendapatkan data-data yang di perlukan. 


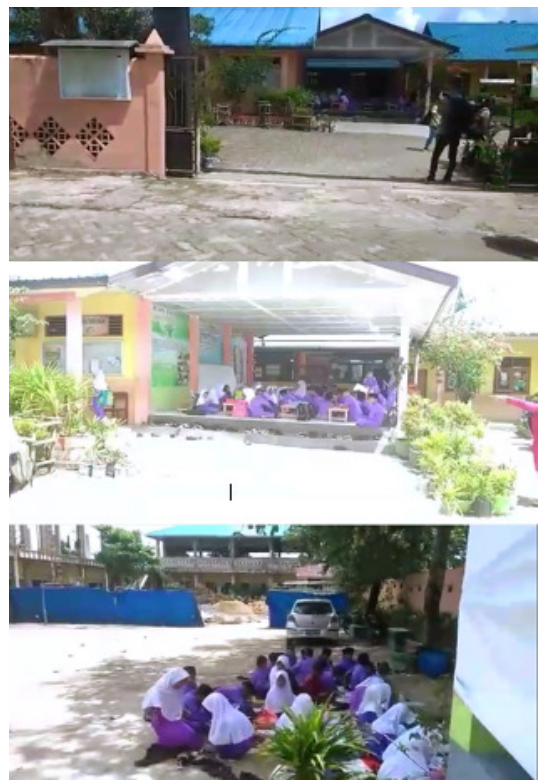

Gambar 13. Suasana di SDN 011 Tanjung pinang timur

Metode etnografi yang diterapkan pada penelitian ini adalah peneliti sebagai peserta, dimana kelompok yang sedang diteliti mengetahui tentang keberadaan peneliti, namun peneliti tidak ikut serta melakukan kegiatan dan aktifitas didalam kelompok yang sedang diteliti. Pada Gambar 14 memperlihatkan peneliti melakukan proses pengumpulan informasi di SDN 011 Tanjung pinang timur.

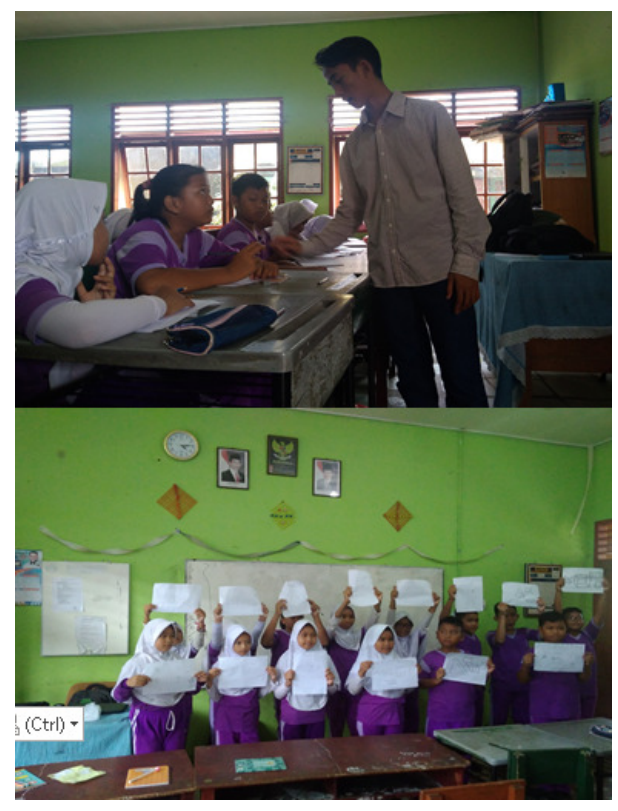

Gambar 14. Mengumpulkan informasi mengenai permasalahan yang terdapat di sekolah melalui siswa

\section{HASIL DAN PEMBAHASAN}

Tahapan selanjutnya adalah curahan gagasan permasalahan yang ditemukan di sekolah dari hasil observasi, dimana semua permasalahan yang ditemukan akan di dokumentasikan. Proses ini adalah merupakan tahapan yang penting, karena sangat diharapkan bahwa solusi yang akan dihasilkan adalah merupakan solusi yang dibutuhkan, bukan solusi yang diminta oleh calon pengguna. Pola penyampaian gagasan secara bebas akan sangat diperlukan untuk memotivasi peneliti untuk mampu berpikir inovatif dan kreatif. Curahan gagasan yang bersifat luas adalah merupakan pondasi bagi rekayasawan untuk mampu menghasilkan sebuah inovasi yang berbasiskan teknologi. Hal ini sering dipahami dengan $\mathrm{T}$ concept, dimaksudkan bahwa inovasi yang dihasilkan memiliki pengaruh yang luas dan mendalam. Pada Gambar 15 dapat dilihat proses pengumpulan masalah-masalah yang sangat berkaitan dengan kejadian di sekolah selama melakukan observasi dan wawancara

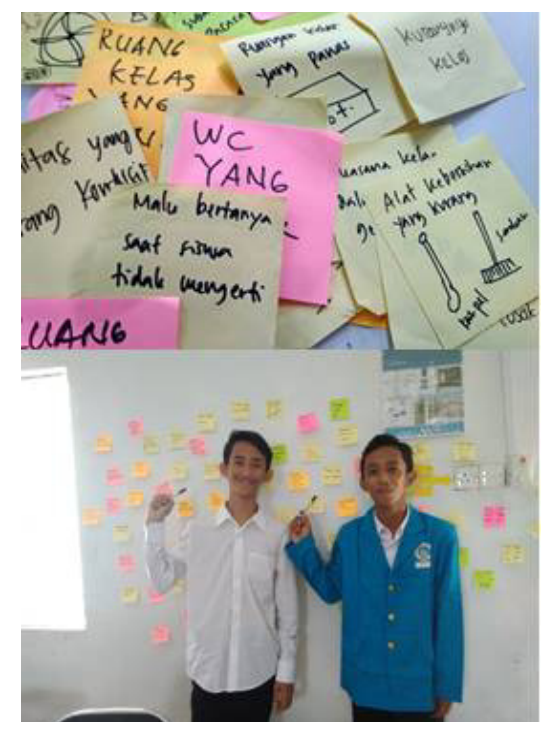

Gambar 15. Proses pengumpulan masalah

Permasalahan utama adalah satu permasalahan yang akan dijadikan landasan untuk langkah penentuan solusi, dalam tahapan ini akan dilakukan proses pengerucutan masalah, dimulai dengan pengelompokan masalah dan selanjutnya di pilih satu masalah saja, lihat Gambar 16. Proses diskusi bersama sesama anggota kelompok dengan saling memberikan penjelasan terhadap masalah yang akan dijadikan masalah utama diperlukan untuk mendapatkan informasi-informasi yang belum 
dapat disampaikan pada tahapan sebelumnya. Adapun permasalahan utama dari penelitian ini adalah air keruh..

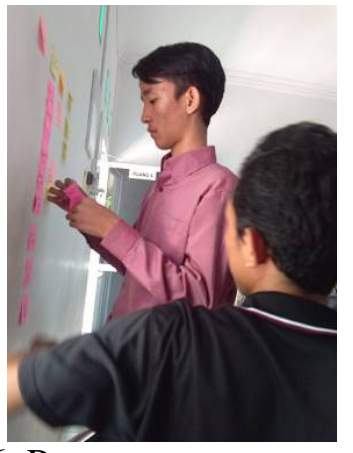

Gambar 16. Proses pengerucutan masalah untuk mendapatkan masalah utama

Tahapan curahan gagasan solusi dari masalah utama dilakukan setelah mendapatkan permasalahan utama. Dalam tahapan ini akan disampaikan beberapa konsep solusi bersama anggota peneliti lainnya. Dengan mempergunakan alat tulis yang dituangkan kedalam sketsa. Pada Gambar 17 menampilkan konsep solusi utama berupa perangkat filtrasi air.

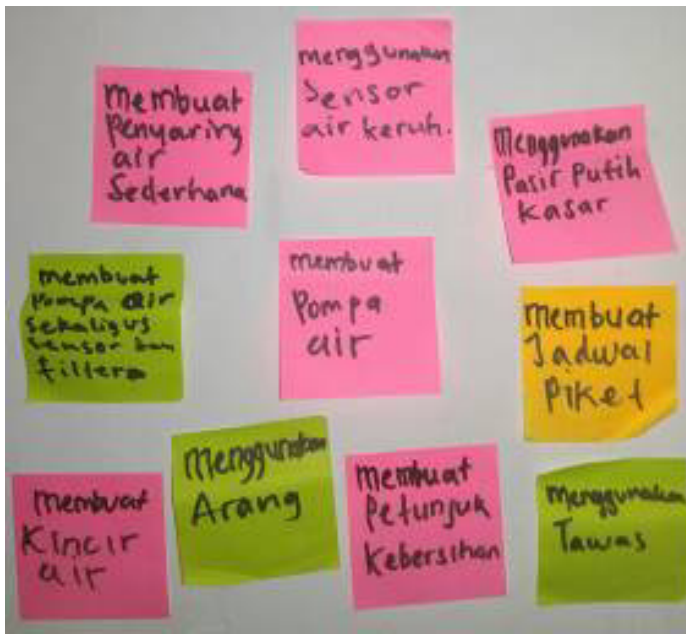

Gambar 17. Konsep-konsep solusi

\section{Purwarupa}

Tahapan yang sudah mulai memerlukan pembiayaan adalah tahapan pembuatan purwarupa. Oleh sebab itu pada Proses Desain Rekayasa ini, menekankan untuk mampu menghasilkan purwarupa sederhana yang ekonomis dan fleksible, dengan maksud bahwa perubahan rancangan dapat dilakukan dengan mudah dan tidak akan memerlukan pembiayaan yang besar. Purwarupa dalam tahapan ini lebih dikenal dengan istilah low resolution prototype (Nusyirwan dkk, 2017). Dapat dilihat pada
Gambar 18 adalah sebuah purwarupa sederhana dari penyaringan air keruh.

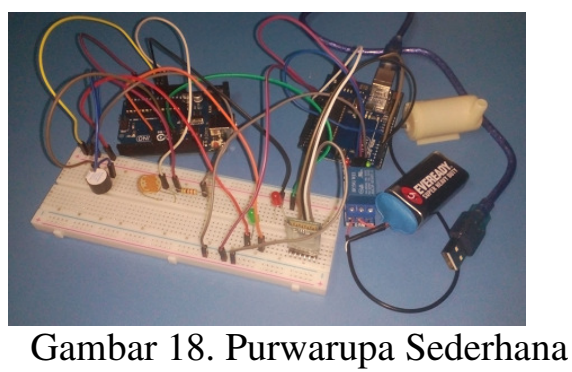

\section{Pengujjian Kegunaan}

Pengujian kegunaan adalah proses evaluasi terhadap inovasi yang dirancang dengan berbasis pengguna. Pada tahapan ini pengguna akan berpartisipasi dan berinteraksi secara langsung dengan purwarupa sederhana yang dihasilkan dari proses sebelumnya. Pengguna akan diminta untuk melakukan tugas tertentu atau hanya menjelajahinya secara bebas, sementara perilaku pengguna diamati dan dicatat untuk mengidentifikasi kelemahan desain yang menyebabkan kesalahan atau kesulitan pengguna. Selama pengamatan ini, Setelah kelemahan desain telah diidentifikasi, rekomendasi desain diusulkan untuk meningkatkan kualitas ergonomis produk (Bastien dkk, 2010).

Pengalaman pengguna akan memperluas pandangan tentang interaksi produk dengan pengguna dari aspek emosional. Adapun motivasi dari proses pengalaman pengguna adalah untuk mengembangkan pengalaman dan emosi positif. Oleh karena itu, produk harus memenuhi kebutuhan psikologis dan motif pelanggan (Von Saucken dkk, 2014).

Pada Gambar 19 menampilkan pengujian

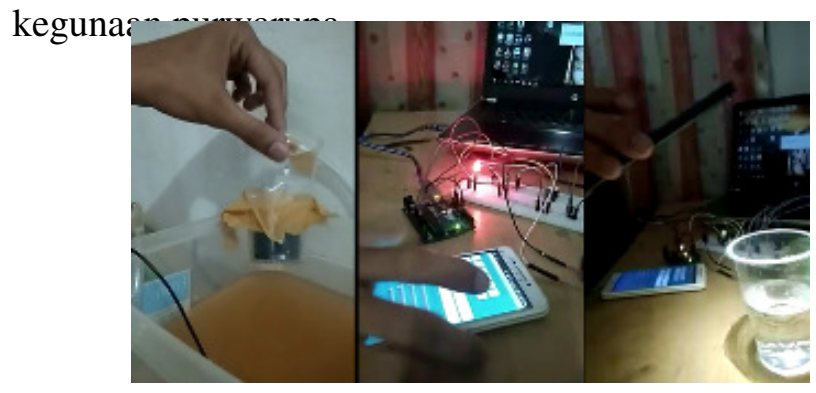

Gambar 19. Pengujian kegunaan 


\begin{tabular}{|c|l|l|}
\hline Kondisi & LED merah & Pengujian \\
air keruh & menyala dan & pada air yang \\
pada & buzzer & sudah jernih, \\
awal & berbunyi, & dimana LDR \\
pengujian & karena air & mendapatkan \\
& keruh. & cahaya., LED \\
& Pompa mini & hijau \\
& dihidupkan & menyala, \\
& melalui & buzzer \\
& bluetooth & berhenti. \\
\hline
\end{tabular}

Inovator yang berbasiskan teknologi sangat sadar bahwa kesuksesan hasil inovasi tidak hanya dilihat dari manfaat dari produk yang akan dihasilkan namun juga perlu memperhatikan faktor pengalaman pengguna., sehingga pengembangan inovasi teknologi tidak lagi hanya tentang mengimplementasikan fitur dan menguji kegunaannya, tetapi juga tentang mendesain produk yang menyenangkan dan mendukung kebutuhan dan nilai-nilai dasar manusia. Dengan demikian, pengalaman pengguna dalam tahapan Proses Desain Rekayasa harus menjadi perhatian utama pengembangan produk.

\section{Program pada Arduino}

Dibawah ini adalah program yang ditulis pada Arduino untuk dapat menghasilkan luaran sesuai.Pada Gambar 21 menampilkan pemograman Arduino untuk LED, Buzzer dan LDR.

\begin{tabular}{|l|}
\hline byte ldr= A2; \\
byte ledred=13; \\
byte ledgreen = $;$ \\
byte buzzer = 12; \\
int nilai; \\
void setup()\{ \\
pinMode(ledred, OUTPUT); \\
pinMode (buzzer, OUTPUT); \\
pinMode(ledgreen, OUTPUT); \\
Serial.begin(9600); \\
\} \\
void loop()\{ \\
nilai= analogRead(ldr); \\
Serial.print("Nilai LDR: "); \\
Serial.println(nilai); \\
if(nilai < 100)\{ \\
tone(buzzer, 100); \\
digitalWrite(ledred, HIGH);
\end{tabular}

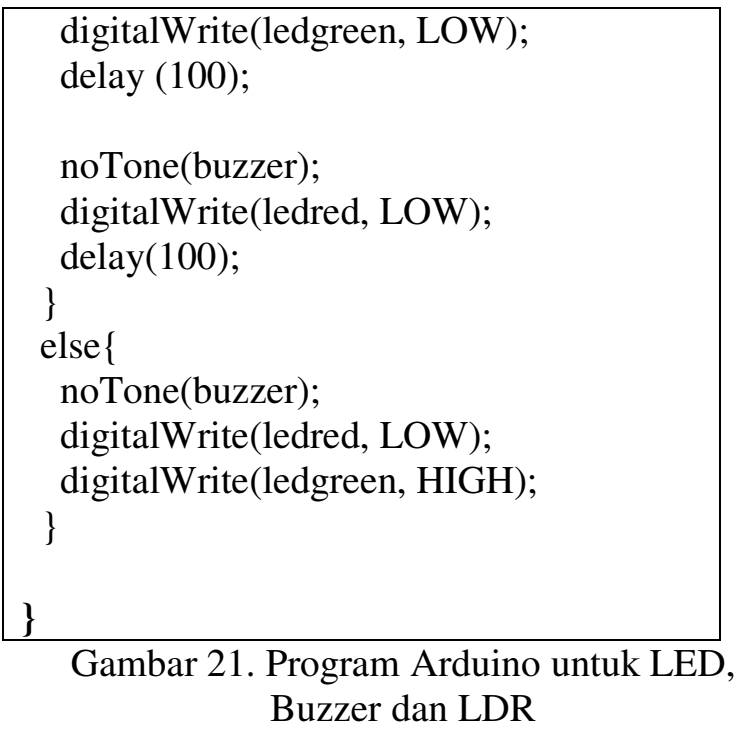

Sedangkan pada Gambar 22 menampilkan program Arduino untuk Bluetooth dan pompa air mini.

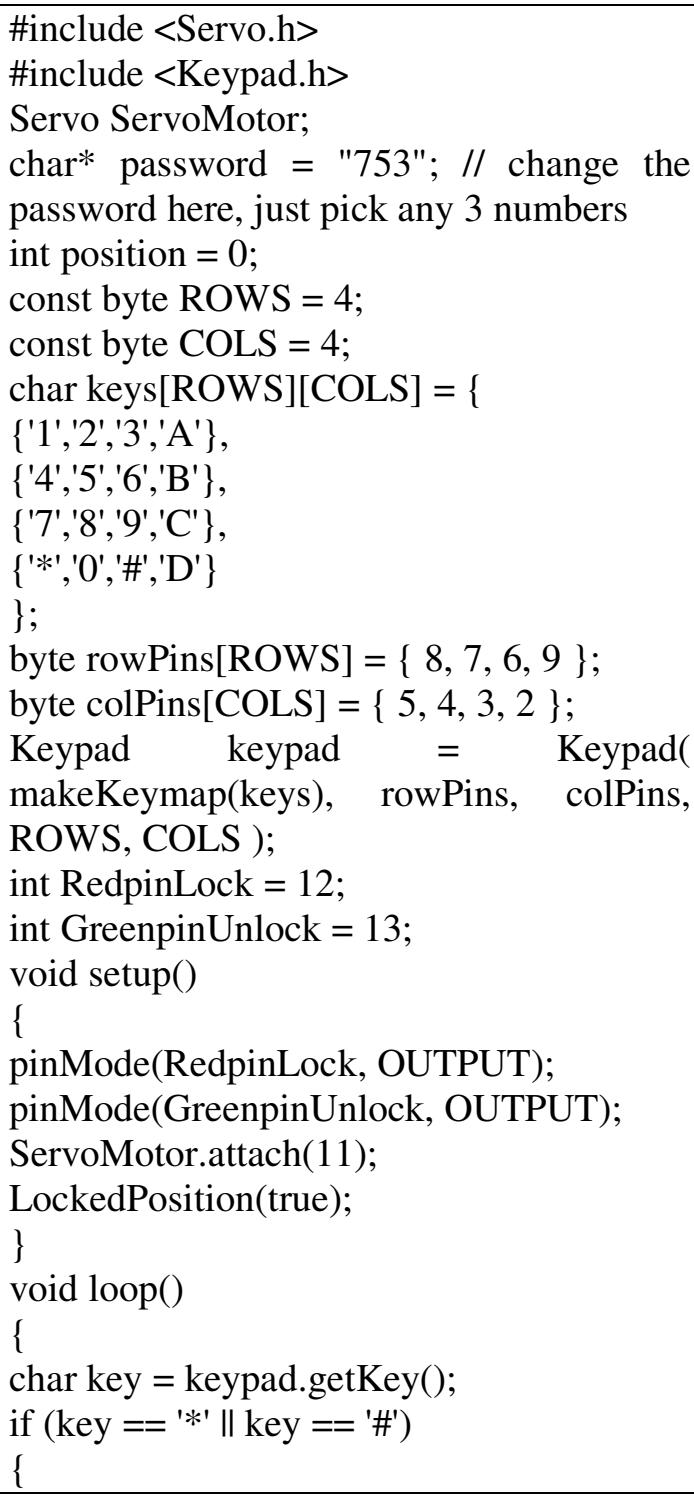




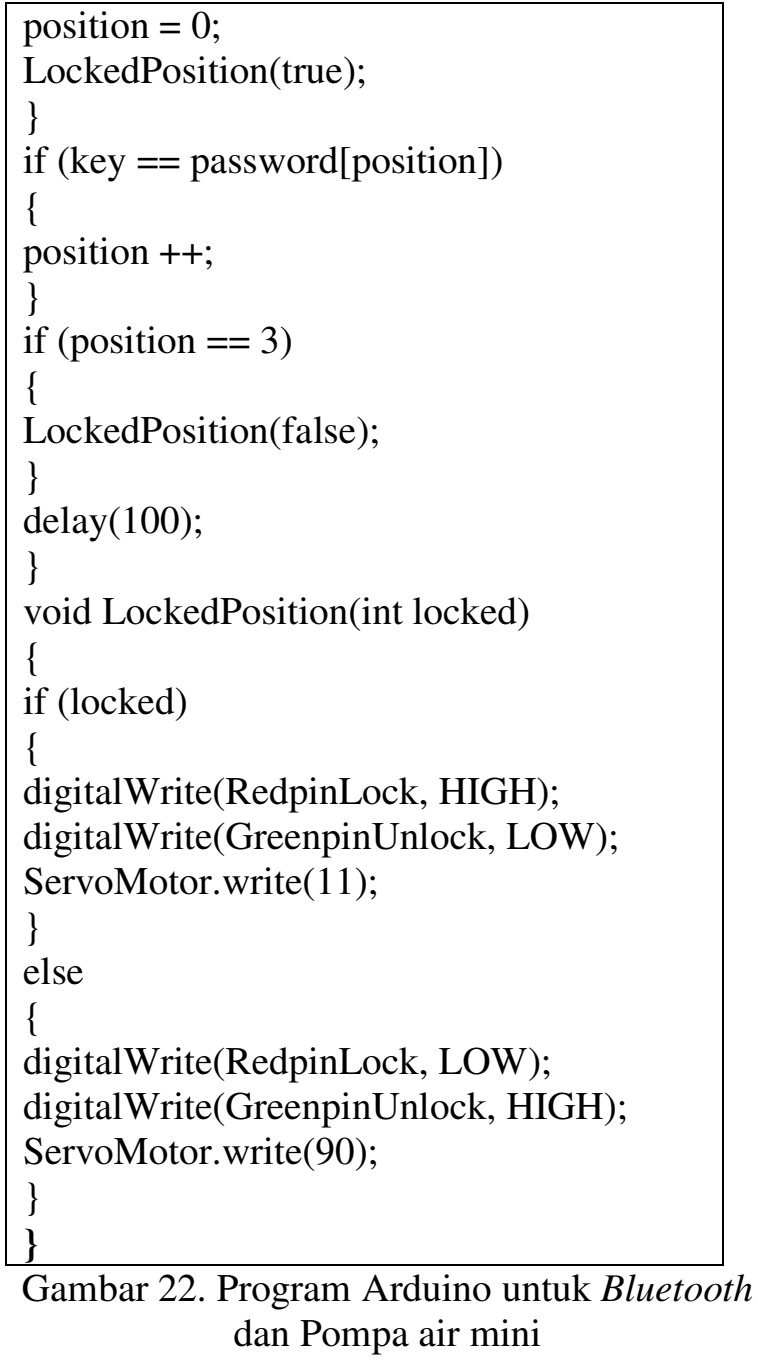

\section{Kesimpulan}

KESIMPULAN DAN SARAN

Inovasi berbasis teknologi penyaringan air keruh menggunakan sensor LDR dan Bluetooth adalah merupakan solusi untuk mendapatkan air bersih untuk keperluan siswa dan guru di sekolah sehingga terhindar dari penyakit dan bakteri.Dari hasil pengujian didapatkan bahwa purwarupa dapat berfungsi dengan baik.

\section{Saran}

Teknologi digitalisasi yang di perkenalkan di revolusi industri 4.0, adalah merupakan tantangan bagi perguruan tinggu untuk mampu mendesiminasikan hasil penelitian kepada masyarakat. Oleh sebab itu diperlu dukungan dari pemerintah daerah dalam memberikan pernguatan penguasaan teknologi dengan menggunakan arduino di sekolah.

\section{UCAPAN TERIMA KASIH}

Terima kasih kepada civitas akademika di jurusan teknik elektro Universitas Maritim Raja Ali Haji (UMRAH) dan redaksi Logista : Jurnal Ilmiah Pengabdian kepada Masyarakat Universitas Andalas yang telah memberikan kesempatan untuk publikasi.

\section{DAFTAR PUSTAKA}

Wiguna, P. M. A. H. Ichsan, and H. Fitriyah, Rancang Bangun Filter Air Berbasis Arduino Pada Penampungan Air Menggunakan Metode Fuzzy, Jurnal Pengembangan Teknologi Informasi dan Ilmu Komputer, Vol. 2, No. 10, pp 34423450, 2018.

Susanto, D. T. U. Kalsum, and Y. Suzantri, Alat penyaring air kotor menjadi air bersih menggunakan mikrokontroller atmega 32, Jurnal Media Infotama, Vol. 10 No. 2, pp 142-150,2014

Gusdi, R. H. Wita,and U. Septiana, Alat Penyaringan Air Sederhana Dengan Metode Fisika, Jurnal Nasional Ecopedon, Vol. 4 No.1, pp 19-21, 2017

Ramadhan, M.S. dan M. Rivai,Sistem Kontrol Tingkat Kekeruhan Pada Aquarium Menggunakan Arduino Uno, JURNAL TEKNIK ITS Vol. 7, No. 1, pp A87- A91, 2017

Kastner, S. \& R. T. Knight, Bringing Kids into the Scientific Review Process. Neuron, Vol. 93, Edisi 1, pp 12-14, Elsevier Inc, 2017

Irbīte, A. \& A. Strode, Design thinking models in design research and education, Proceedings of the International Scientific Conference. Vol. IV, pp 488-500, 2016 https://id.pinterest.com/pin/2181437943076137 7/, retrieved May 31, 2019.

http://web.stanford.edu, retrieved May 26, 2019. https://www.google.com/maps/place/Jl.+Tj.+Sia mbang/@0.87153,104.4258334,10z/data=!4 m5!3m4!1s0x31d90d330974d24d:0xcd400 be $497706 a c ! 8 m 2 ! 3 d 0.87153 ! 4 d 104.428022$ 1, retrieved May 26, 2019.

Wagner, C. B. Kawulich, \& M. Garner, Collecting Data Through Observation, Doing Social Research: A global context, McGraw Hill, 2012

Nusyirwan, D. Engineering Design Process Engineering Student Centered Experience Learning (ESCEL) di Jurusan Teknik 
Elektro Universitas Maritim Raja Ali Haji (UMRAH). Jurnal Sustainable Vol. 06, No. 01, pp. 24-35, 2017

Bastien, J.M. C. Usability testing: a review of some methodological and technical aspects of the method", International Journal of Medical Informatics, Vol. 79, Edisi 4, pp e18-e23, Elsevier Ireland Ltd, 2010

von Saucken, C.F. Lachner dan U. Lindemann, Principles for User Experience What We
Can Learn from Bad Examples, International Conference on Kansei Engineering \& Emotion Research, 2014

Johnson, G. I. \& C. W. Clegg, \& S. J. Ravden, Towards Practical User Experience Evaluation Methods, Applied Ergonomics, Volume 20, Edisi 4, pp 255-260, Elsevier Ltd 